\title{
A Study on Pregnancy Outcome in Women with First Trimester Bleeding Per Vaginum
}

\author{
Dr.Manonmani MD,DGO ${ }^{1}$, Dr.Nandhini DGO,DNB(OG) ${ }^{2}$ \\ ${ }^{1}$ Head Of The Department \\ ${ }^{2}$ Assistant Professor \\ Department Of Obstetrics And Gynecology, Coimbatore Medical College Hospital,Coimbatore,Tamilnadu.
}

\begin{abstract}
Aim: To find out the effect of threatened miscarriage on pregnancy outcome.
Objectives: To find out the percentage of pregnant women with first trimester bleeding per vaginum which end up in first trimester miscarriage, second trimester miscarriage,preterm labour and full term labour.

Materials And Methods: A prospective study was carried out at Coimbatore Medical College Hospital ,Coimbatore.Pregnant women admitted in labour ward with bleeding per vaginum during first trimester were taken up for study. 150 patients were taken up for study during the period of one year from January 2015 to January 2016.A structured proforma was used to collect information and followed till their pregnancy terminated.

Inclusion criteria: Singleton pregnancy upto 13 weeeks with positive fetal cardiac activity.

Exclusion criteria: Ectopic and Molar gestation.

Information regarding age,socio economic status, gravida, details about previous pregnancies, medical disorders are received in addition to routine antenatal history and type of antenatal care received and total number of visits and timing of first booking visit.

Examination included both general and obstetrical.Basic lab investigations are done during admission.Gestational age and viability confirmed by USG and presence of subchorionic hemorrhage noted (volume of the bleed not measured).Patients are started on progesterone support and advised bed rest.Once bleeding stops repeat USG done for fetal well being then discharged and followed up.
\end{abstract}

\section{Observation And Results}

Table 1 Distribution of patients according to gravida

\begin{tabular}{|l|l|l|l|l|}
\hline Gravida & Frequency & Percent & Valid percent & Cumulative percent \\
\hline 1 & 87 & 58.0 & 58.0 & 58.0 \\
\hline 2 & 57 & 38.0 & 38.0 & 96.0 \\
\hline 3 & 6 & 4.0 & 4.0 & 100.0 \\
\hline Total & 150 & 100.0 & 100.0 & \\
\hline
\end{tabular}

In the present study out of 150 patients $58 \%$ were primi, $38 \%$ were second gravida, $6 \%$ were third gravida.

Table 2 : Age distribution

\begin{tabular}{|l|l|l|l|l|}
\hline Age & Frequency & Percent & Valid percent & Cumulative percent \\
\hline$<20$ & 21 & 14.0 & 14.0 & 14.0 \\
\hline $21-25$ & 57 & 38.0 & 38.0 & 52.0 \\
\hline $26-30$ & 63 & 42.0 & 42.0 & 94.0 \\
\hline$>30$ & 9 & 6.0 & 6.0 & 100.0 \\
\hline Total & 150 & 100.0 & 100.0 & \\
\hline
\end{tabular}

In the present study $14 \%$ were in the age group less than 20 years.Majority (42\%) were in the age group between $26-30$ year.

Table 3: Distribution according to the presence of sub chorionic hemorrhage( $\mathrm{SCH})$

\begin{tabular}{|l|l|l|l|l|}
\hline USG & Frequency & Percent & Valid percent & Cumulative percent \\
\hline Normal & 123 & 82.0 & 82.0 & 82.0 \\
\hline SCH & 27 & 18.0 & 18.0 & 100.0 \\
\hline Total & 150 & 100.0 & 100.0 & \\
\hline
\end{tabular}

The patients with sub chorionic hemorrhage were $18.0 \%$ (USG evidence) volume of bleed not measured.

Table 4 Correlation between subchorionic hemorrhage( $\mathrm{SCH})$, gestational age(GA) and pregnancy outcome

\begin{tabular}{|l|l|l|l|l|}
\hline $\begin{array}{l}\text { GA with } \\
\text { SCH }\end{array}$ & Frequency & Abortion & Preterm delivery & Term delivery \\
\hline$<8$ weeks & 18 & 12 & 1 & 5 \\
\hline $8-12$ weeks & 9 & 1 & 2 & 6 \\
\hline
\end{tabular}


Out of 18 patients with SCH in less than 8 weeks of GA 12 ended in miscarriage,whereas in 9 patients with SCH 8-12 weeks only 1 patient had miscarriage.

Table 5: Gestational age at the time of bleeding

\begin{tabular}{|l|l|l|l|l|}
\hline $\begin{array}{l}\text { Gestational } \\
\text { age }\end{array}$ & Frequency & Percent & Valid percent & Cumulative percent \\
\hline$<8$ weeks & 63 & 42.0 & 42.0 & 42.0 \\
\hline$>8$ weeks & 87 & 58.0 & 58.0 & 100.0 \\
\hline Total & 150 & 100.0 & 100.0 & \\
\hline
\end{tabular}

About $42 \%$ of patients had bleeding at less than 8 weeks of gestation and $58 \%$ patients had bleeding above 8 weeks of gestation.

Table 6: Outcome of pregnancy

\begin{tabular}{|l|l|l|l|l|}
\hline Outcome & Frequency & Percent & Valid percent & Cumulative percent \\
\hline Abortion 1 trimester & 21 & 14.0 & 14.0 & 14.0 \\
\hline Abortion 2 trimester & 6 & 4.0 & 4.0 & 18.0 \\
\hline Preterm & 21 & 14.0 & 14.0 & 32.0 \\
\hline Full term & 102 & 68.0 & 68.0 & 100.0 \\
\hline Total & 150 & 100.0 & 100.0 & \\
\hline
\end{tabular}

Majority of patients with first trimester bleeding (68.0\%) had full term delivery,21\% had first trimester abortion, $21 \%$ of patients ended in preterm delivery and $6 \%$ had second trimester abortion.

Table 6 Distribution according to birth weight

\begin{tabular}{|l|l|l|l|}
\hline S.NO & Birth weight $(\mathrm{kg})$ & Frequency & Percentage\% \\
\hline 1. & $<1.5$ & 6 & 4.9 \\
\hline 2. & $1.6-2.0$ & 18 & 14.6 \\
\hline 3. & $2.1-2.5$ & 33 & 26.8 \\
\hline 4. & $2.6-3.0$ & 84 & 43.9 \\
\hline 5. & $>3.0$ & 12 & 9.8 \\
\hline Total & & 123 & 100.0 \\
\hline
\end{tabular}

In the present study $44 \%$ delivered babies weighing $2.6-3.0 \mathrm{~kg}$.

Table 7: Apgar At One Minute

\begin{tabular}{|l|l|l|l|l|}
\hline APGAR & Frequency & Percent & Valid percent & Cumulative percent \\
\hline$<5$ & 9 & 7.3 & 7.3 & 7.3 \\
\hline $5-8$ & 87 & 70.7 & 70.7 & 78.0 \\
\hline$>8$ & 27 & 22.0 & 22.0 & 100.0 \\
\hline Total & 123 & 100.0 & 100.0 & \\
\hline
\end{tabular}

About $70 \%$ of babies had one minute APGAR between 5-8.APGAR of the babies depend on various factors like meconium aspiration,prematurity, birth asphyxia.

\section{Discussion}

Although first trimester vaginal bleeding per vaginum is commonly considered as a marker of a pregnancy at risk for adverse outcomes, only a few studies have vigourously investigated the prevalence and predictors of bleeding.Estimates of bleeding prevalence in early pregnancy are imprecise and range from 7-24 $\%$. In the present study first trimester bleeding per vaginum was seen mainly in primigravida $58 \%$ as compared with various studies.According to study by Gianpaolo et al the risk of spontaneous miscarriage is related to gestational age and is significantly increased if diagnosed less than 9 weeks of gestation and affect the pregnancy outcome.In the present study out of 18 patients with subchorionic bleed in <8 week gestation 12 patients ended in miscarriage indicating that $\mathrm{SCH}$ in first trimester influences the pregnancy outcome.

According to Yang analysis $25 \%$ of women presented with bleeding per vaginum with increased incidence during first completed month of pregnancy where as in our study it is $18 \%$.In Alexan study patients with bleeding at 8 weeks of gestation had increased incidence of preterm delivery, in our study out of 21 patients had miscarriage in first trimester, 1 second trimester miscarriage and 15 had term delivery.Among 123 live births $44 \%$ had birth weight between $2.5-3.0 \mathrm{~kg}$ APGAR at one minute was 5-8 in $70 \%$ of babies in our study. 


\section{Summary}

The outcome of pregnancy in patients with bleeding was not influenced by age and gravida.It was seen that results were dependent on the period of gestation during which the bleeding occur and associated subchorionic bleeding.The study also reveals that the perinatal outcome is not influenced by bleeding in first trimester.

\section{Conclusion}

From the study it can be concluded that the bleeding in the first trimester was more common in primi gravid,in the age group of 26-30 years.In pregnancies less than 8 weeks associated with sub chorionic bleed there is increased risk of miscarriage.There is no effect on perinatal outcome when the patient reached term.The outcome of the fetus was not influenced by bleeding in the first trimester.

Early diagnosis,bed rest,progesterone support will help in continuing the pregnancy with good fetal outcome.

\section{Bibliography}

[1]. Ittels KA, Pelletier AJ, Brown DF, Camargo CA., Jr United States emergency department visits for vaginal bleeding during early pregnancy, 1993-2003. Am J Obstet Gynecol. 2008;198:523.e1-6. [PubMed]

[2]. Calleja-Agius J. Vaginal bleeding in the first trimester. Br J Midwifery. 2008;16:656-61.

[3]. Poulose T, Richardson R, Ewings P, Fox R. Probability of early pregnancy loss in women with vaginal bleeding and a singleton live fetus at ultrasound scan. J Obstet Gynecol. 2006;26:782-4. [PubMed]

[4]. Schauberger CW, Mathiason MA, Rooney BL. Ultrasound assessment of first-trimester bleeding. Obstet Gynecol. 2005;105:333[PubMed]

[5]. Fleischer AC, Andreotti RF, Bohm-Velez M, Fishman EK, Horrow MM, Hricak H. American College of Radiology (ACR) Appropriateness Criteria; 2007. First trimester bleeding; p. 5. Available from:www.acr.org.

[6]. Luise C, Jermy K, May C, Costello G, Collins WP, Bourne TH. Outcome of expectant management of

[7]. Luise C, Jermy K, May C, Costello G, Collins WP, Bourne TH. Outcome of expectant management of spontaneousfirst trimester miscarriage: Observational study. BMJ. 2002;324:873-5. [PMC free article][PubMed]

[8]. Sotiriadis A, Makrydimas G, Papatheodorou S, Ioannidis JP. Expectant, medical, or surgical management of first-trimester miscarriage: A meta-analysis. ObstetGynecol. 2005;105:1104-13. [PubMed]

[9]. Tang OS, Lau WN, Ng EH, Lee SW, Ho PC. A prospective randomized study to compare the use of repeated doses of vaginal with sublingual misoprostol in the management of first trimester silent miscarriages.Hum Reprod. 2003;18:176-81. [PubMed]

[10]. Wieringa-de Waard M, Ankum WM, Bonsel GJ, Vos J, Biewenga P, Bindels PJE. The natural course of spontaneous miscarriage: Analysis of signs and symptoms in 188 expectantly managed women. Br J Gen Pract. 2003;53:704-8. [PMC free article] [PubMed]

[11]. Zhang J, Gilles JM, Barnhart K, Creninin MD, Westhoff C, Frederick MM, et al. A comparison of medical management with misoprostol and surgical management for early pregnancy failure. N Engl J Med.2005;353:761-9. [PubMed]

[12]. Ananth C, Savitz D. Vaginal bleeding and adverse reproductive outcomes: a meta-analysis. Paediatr Perinat Epidemiol. 1994;8:6278. [PubMed]

[13]. Snell BJ. Assessment and Management of Bleeding in the First Trimester of Pregnancy. Journal of Midwifery \& Women's Health. 2009;54:483-91. [PubMed]

[14]. Dogra V, Paspulati RM, Bhatt S. First trimester bleeding evaluation. Ultrasound Q. 2005;21:69-85.[PubMed]

[15]. Amirkhani Zh, Akhlaghdoust M, Rabie Salehi G, Jangholi E, Sadeghi M, Ghenaat F, et al. Relation between Fluoxetine and Menstrual Cycle Disorders. Journal of Family and Reproductive Health. 2012;6:95-8.

[16]. Deutchman M, Tubay AT, Turok D. First trimester bleeding. Am Fam Physician. 2009;79:985-94.[PubMed] 